\title{
Comparative Efficacy of Metformin and Sulfonylurea in Monotherapy or Combination for Type 2 Diabetes
}

\author{
Lina Eltaib ${ }^{1 *}$ and Shamayl M. Alenzi \\ 'Department of Pharmaceutics, Faculty of Pharmacy, Northern Border University, Arar, Saudi Arabia; \\ linasalaheldin@gmail.com \\ 2Department of Pharmacy, Northern Area Armed Forces Hospital, Saudi Arabia; leen2007baha@hotmail.com
}

\begin{abstract}
Despite the extensive efforts of physicians to achieve better control and management for blood glucose level in type 2 diabetics, maintaining near normal blood glucose level in these patients remain unsatisfactory. The objective of the study was to compare the effectiveness of sulfonylureas, metformin and combination of metformin plus sulfonylureas in controlling blood glucose in type 2 diabetics. Retrospective cohort research design conducted during the period of two months from $1^{\text {st }}$ November 2019 to $1^{\text {st }}$ March 2020 at Northern Area Armed Forces Hospital in Hafr Al Batin- Saudi Arabia on sample of 217 diabetic patients' files, all data coded with serial number and analyzed by SPSS program through and inferential and descriptive statistics. Mean decrease in HbA1c for metformin therapy was 1.5(\%), for sulfonylurea was 1.4(\%), for combination therapy was $1.9(\%)$. Mean decrease in HbA1c fasting blood glucose for metformin therapy was $1.8(\mathrm{mmol} / \mathrm{l})$, for sulfonylurea was $1.6(\mathrm{mmol} / \mathrm{l})$, for combination therapy was $3(\mathrm{mmol} / \mathrm{l})$. Mean decrease in postprandial blood glucose for metformin therapy was $3.2(\mathrm{mmol} / \mathrm{l})$, for sulfonylurea therapy was $3(\mathrm{mmol} / \mathrm{l})$, for combination therapy was $3.7(\mathrm{mmol} / \mathrm{l})$. There was a significant difference between levels of HbA1c between metformin group and combination group (metformin and sulfonylurea) $(p=0.002)$ and also there was a significant difference between sulfonylurea group and combination group (metformin and sulfonylurea) in relation to HbA1c levels $(p=0.001)$. However, there was no significant difference between metformin and sulfonylurea in decreasing HbA1c $(p=0.09)$. In conclusion, metformin or sulfonylurea as a single therapy is similar in efficacy in reducing glycosylated hemoglobin level, fasting and post-prandial plasma glucose levels to equal degree. However, combination of both therapies resulted in significant greater control of blood glucose level.
\end{abstract}

Keywords: Combination Type 2 Diabetes, Efficacy, Metformin, Monotherapy, Sulfonylureal

\section{Introduction}

Diabetes Mellitus (DM) is one of the major fast growing Non-Communicable Disease (NCD) threats to global public health. Trends in the incidence of diabetes indicate a disproportionate increase due to current rapid demographic transitions from traditional to more westernized and urbanized lifestyles ${ }^{1}$.
The epidemiologic transition in the Kingdom of Saudi Arabia (KSA) has been fast and complete. Rapid economic growth during the last 4 decades led to a remarkable increase in living standards and adoption of a 'Westernized' lifestyle, characterized by unhealthy dietary patterns, and decreased physical activity ${ }^{2}$. An increase in the prevalence of T2DM is also observed during the same period, which is attributed to the

${ }^{*}$ Author for correspondence 
dramatic changes in lifestyle, in addition to genetic predisposition of Saudi people to diabetes, and a high prevalence of consanguineous marriages ${ }^{3}$. A national survey in 2004 estimated that $23.7 \%$ of Saudi adults (age 30-70 years) suffered from T2DM, and another $14.1 \%$ had impaired fasting glucose ${ }^{4}$. Prevalence of diabetes was significantly higher in urban areas $(25.5 \%$ versus $19.5 \%$ in the rural areas). The burden of diabetes in KSA is likely to increase to disastrous levels, unless a comprehensive epidemic control program is implemented rigorously promoting healthy diet, exercise and active lifestyles, and curbingobesity ${ }^{5,6}$.

Type 2 diabetes is defined as a syndrome characterized by insulin deficiency, insulin resistance and increased hepatic glucose output ${ }^{7}$ leading to hyperglycemia which subsequently result in irreversible damage in a wide range of tissues e.g. in retine (retinopathy), in kidney (diabetic nephropathy), in nervous tissue (diabetic neuropathy) ${ }^{8}$. T2DM present with many symptoms such as polyuria, polydipsia, polyphagia. In severe cases, hyperglycemia leads to diabetic ketoacidosis or non ketotic hyperosmolar state which may develop to coma and death if not treated properly ${ }^{9}$.

Medications used to treat type 2 diabetes are designed to correct one or more of these metabolic abnormalities. Currently, there are five distinct classes of hypoglycemic agents available, each class displaying unique pharma cologic properties. These classes are the sulfonylureas, meglitinides, biguanides, thiazolidinediones and alphaglucosidase inhibitors ${ }^{10}$. In patients for whom diet and exercise do not provide adequate glucose control, therapy with a single oral agent can be tried. When choosing an agent, it is prudent to consider both patient- and drugspecific characteristics. If adequate blood glucose control is not attained using a single oral agent, a combination of agents with different mechanisms of action may have additive therapeutic effects and result in better glycemic control ${ }^{11}$.

\subsection{Rationale}

Despite the extensive efforts of physicians to achieve better control and management for blood glucose level in type 2 diabetics, maintaining near normal blood glucose level in these patients remain unsatisfactory. This continues to pose a real challenge to physicians as the prevalence of this disease in the Saudi Arabia continues to rise. However, no sufficient studies investigating the effect of oral ant diabetics on blood glucose of type 2 diabetic patients in Saudi Arabia.

\subsection{Objective of the Study}

- To compare the effectiveness of sulfonylureas, metformin and combination of metformin plus sulfonylureas in controlling blood glucose in type 2 diabetics.

- To investigate which is the best and effective oral hypoglycemic agent in controlling of blood glucose level in type 2 Diabetes Mellitus patients.

\section{Literature Review}

Saudi Arabia is now considered among the countries with highest prevalence of DM in the world with incidence reaching as high as $23.7 \%{ }^{12}$ and diabetes is the most challenging health problem facing this country ${ }^{13}$. According to a report by the Saudi Arabian Ministry of Health, approximately 0.9 million people were diagnosed with diabetes in 1992, but this figure increased to 2.5 million people in 2010, representing a 2.7 times increase in the incidence rates in less than two decades. In 2015, 4660 patients with diabetes attended the family and medical clinics across Saudi Arabia ${ }^{14}$. This increasing burden of diabetes is due to various factors, including a rising obesity rate and an aging population ${ }^{15}$. Prevalence rates of T2DM were reported in six studies, three of which were nationwide ${ }^{16-18}$. One study was conducted in Riyadh ${ }^{19}$, one in Jeddah ${ }^{20}$ and one in the Eastern province ${ }^{21}$. The studies demonstrated varying prevalence rates in different geographical regions in the country, ranging from $18.2 \%$ (in 2004-2005) in the study conducted in the Eastern province $^{21}$ to $31.6 \%$ in 2011 in the study conducted in Riyadh $^{19}$ nationwide prevalence rate increased from $23.7 \%$ between 1995 and 2000 to $25.4 \%$ between 2007 and $2009^{17,18}$.

A traditional approach to diabetes therapy is to use single oral agent titrated to maximum dosage. If good glycemic control not achieved, addition of another agent is required, in which each of the two agents targets a single pathological defect of type 2 diabetes as its primary mechanism of action ${ }^{22}$.

Treatment of type 2 diabetes is based on interplay of patient characteristics, severity of hyperglycemia and available therapeutic options. Metformin, sulfonylureas (SU) and thiazolidinediones (TZD) are the most studied of the oral medications used worldwide. They play a 
prominent initial role in the type 2 diabetes treatment algorithm recommended by the American Diabetes Association (ADA) and the European Diabetes Association for the Study of Diabetes (EASD) ${ }^{23}$.

Metformin is considered first-line therapy unless not tolerated or contraindicated. Second-line therapy then includes SUs, TZDs, dipeptidyl peptidase-IV (DPP-4) inhibitors, glucagon-like polypeptide-1 (GLP-1) agonists or insulin. The expected improvement in $\mathrm{HbAlc}$ with the use of metformin, SUs and TZDs is approximately 1$1.5 \%{ }^{24}$.

The majority of type 2 diabetes mellitus do not primarily need insulin therapy. The frequency of type 2 diabetes mellitus occurrence in adults is more than in children. The incidence of the disease is increased with age, particularly after 40 years old ${ }^{25}$. Several different mechanisms are included in the reduction of serum glucose level by metformin without increasing insulin secretion, predominately through non pancreatic pathways. Metformin is often called insulin sensitizer as it increases the effects of insulin in the body ${ }^{26}$.

Metformin also suppress the endogenous glucose production in the liver by reducing the rate of gluconeogenesis with little effect on level of ATP in the cell. Metformin achieve beneficial metabolic effects through targeting AMP-activated protein kinase (AMPK). The AMPK is a multi subunit enzyme that is recognized as a major regulator oflipid biosynthesis mechanisms due to its role in the phosphorylation and subsequent inactivation of pivotal enzymes (such as acetyl-CoA carboxylase) ${ }^{26}$. Recent researches strongly suggest that AMPK has a wider role in metabolic regulation, which include many effects including muscle glucose uptake, fatty acid oxidation. So, it is an ideal therapeutic target of type 2 diabetes mellitus. Activation of AMPK on chronic basis may also induce the expression of muscle hexokinase and glucose transporters, mimicking the effects of extensive exercise training. Metformin also showed protective properties against diabetic complications, especially by reducing the diabetes-related deathrate ${ }^{26}$.

The common reported side effects of metformin include abdominal pai, constipation, distension, flatu lence, heartburn, dizziness, headache, upper respiratory infection, taste disturbance and liver function abnormalities which resolve upon discontinuation of metformin ${ }^{27}$.

Sulfonylurea group including \{glyburide, glipizide, glimepiride and glibenclamide\} which act by binding to and inhibiting the ATP-sensitive potassium channels inhibit regulatory subunit sulfonylurea receptor 1 (SUR1) in pancreatic beta cells. This inhibition causes cell membrane depolarization, opening of voltage dependant calcium channels resulting in an increase in intracellular calcium in beta cell and subsequent stimulation of insulin release $^{28}$.

Side effects of sulfonylurea include hypoglycemia, weight gain mainly as a result of their effect to increase insulin levels and thus utilization of glucose and other metabolic fuels. Other side effects include gastrointestinal upset, headache and hypersensitivity reaction ${ }^{28}$.

Metformin and sulfonylurea can be used in combi nation with complementary mechanisms of action to improve glycemic control in patients with type 2 diabetes ${ }^{28}$.

\section{Methodology}

\subsection{Study Design and Setting}

Retrospective cohort research design conducted during the period of two months from $1^{\text {st }}$ November 2019 to $1^{\text {st }}$ March 2020 at Northern Area Armed Forces Hospital in Hafr Al Batin- Saudi Arabia.

\subsection{Study Population, Data Collection and Sampling}

217 diabetic patients' files extracted from hospital database according to inclusion criteria.

\subsection{Inclusion Criteria}

- Type 2 Diabetes Mellitus patients

- Newly prescribed single or combination oral hypog lycemic agents for at least three months within the preceding 12 months of study enrollment

- Have recorded baseline and follow up measurement of HbAlc, fasting and postprandial blood glucose

- Age range more than 30 years.

\subsection{Exclusion Criteria}

- Type 1 Diabetes Mellitus patients on insulin

- Type 2 Diabetes Mellitus patients on oral hypoglycemic agents who changed their therapy

- Type 2 Diabetes Mellitus patients on oral hypoglycemic agents plus insulin 
- Haven't recorded baseline and follow up measurement of $\mathrm{HbAlc}$

- Age below 30 old years or with co-morbidity that might affect diabetes treatment.

\subsection{Data Collection and Data Collection Tool}

A data collection sheet specially designed for the study purpose was used to collect relevant information about patient demographics (age and gender), HbAlc value, and fasting and postprandial blood glucose prior initiation of oral antidiabetic treatment and after at least three months of treatment. The study sample divided into three groups (first group on Metformin, second group on Sulfonylurea and last group both of them), selection flow represented in (Figure 1).

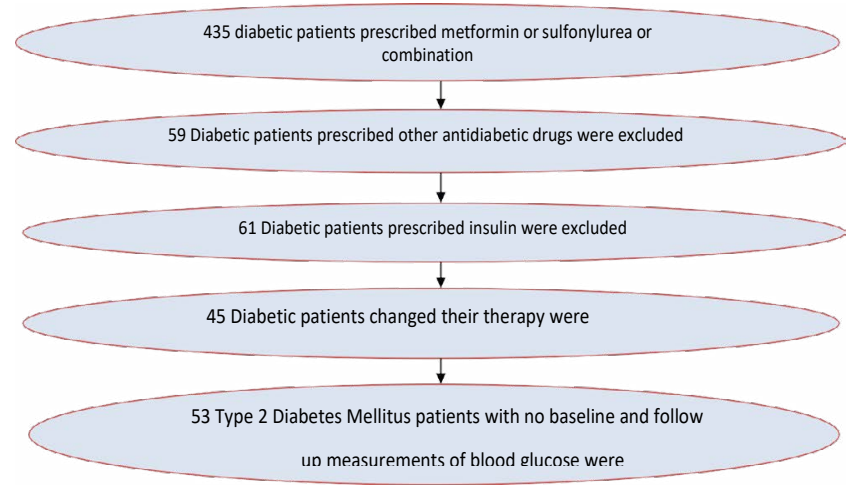

Figure 1. Selection flow of study subjects.

\subsection{Statistical Analysis}

All data coded with serial number and analyzed by SPSS program through descriptive and inferential statistics. Mean and standard deviation calculated for age of diabetic patients, $\mathrm{HbA1c}$, fasting and postprandial blood glucose before and during oral antidiabetic's therapy, ttest used to compare between $\mathrm{HbAlc}$ between different study groups of treatment. (P-value $>0.05$ ) was considered statistically significant.

\section{Results}

\subsection{Demographics of Study Subjects}

From the total sample included in the study, males re present $(63 \%)$ and females represent (37\%). The youngest age among the collected data of the patients was 31 years and the oldest was 86 with mean \pm (SD) $50.3 \pm$ (10.5) (Table 1a).

Among the study sample, there were 70 (32\%) patients on Metformin, 70 (27\%) on Sulfonylureas and 77 (41\%) on combination of these two drugs (Table 1b).

Table 1a. Distribution of the study sample according to their demographic characters $(n=217)$

\begin{tabular}{|c|c|c|c|}
\hline Variable & Categories & Frequency & Percentage (\%) \\
\hline \multirow{2}{*}{ Sex } & Male & 137 & $63 \%$ \\
\cline { 2 - 4 } & Female & 80 & $37 \%$ \\
\hline \multirow{4}{*}{ Age (years) } & $31-45$ years & 80 & $37 \%$ \\
\cline { 2 - 4 } & $46-60$ years & 101 & $46 \%$ \\
\cline { 2 - 4 } & $61-86$ years & 36 & $17 \%$ \\
\cline { 2 - 4 } & \multicolumn{3}{|c|}{ Maximum $=86$ yrs Minimum $=31 \mathrm{yrs}$} \\
& \multicolumn{3}{|c|}{ Mean \pm SD $=50.3 \pm(10.5)}$. \\
\hline
\end{tabular}

Table 1b. Type of oral antidiabetic used $(n=217)$

\begin{tabular}{|c|c|c|}
\hline Oral antidiabetic & Frequency & $\mathbf{\%}$ \\
\hline Metformin & 70 & $32 \%$ \\
\hline Sulfonylurea & $\mathbf{7 0}$ & $\mathbf{2 3 \%}$ \\
\hline $\begin{array}{c}\text { Combination } \\
\text { Therapy }\end{array}$ & $\mathbf{7 7}$ & $36 \%$ \\
\hline
\end{tabular}

\subsection{Change in HbA1c in Diabetic Patients with Metformin Therapy}

Maximum level of $\mathrm{HbAlc}$ before therapy with metformin therapy was 13.9, after therapy the level became 11.2, minimum level of $\mathrm{HbAlc}$ before therapy with metformin was 7.3, after therapy the level became 5.1 and the mean level of $\mathrm{HbA1c}$ was $8.9 \pm 1.7$ and after treatment it was 7.4 \pm 1.3 with difference equal to 1.5 (\%) (Table 2). 
Table 2. Difference in HbAlc level caused by metformin therapy $(n=70)$

\begin{tabular}{|c|c|c|c|c|}
\hline \multicolumn{2}{|c|}{ Variable } & Before therapy with metformin (\%) & After therapy with metformin (\%) & Difference \\
\hline \multirow{3}{*}{$\begin{array}{l}\text { Metformin } \\
\text { therapy }\end{array}$} & $\begin{array}{c}\text { Maximum } \\
(\text { HbAlc) }\end{array}$ & $13.9 \pm 1.9$ & $11.2 \pm 1.4$ & 2.7 \\
\hline & $\begin{array}{c}\text { Minimum } \\
(\text { HbA1c) }\end{array}$ & $7.3 \pm 0.8$ & $5.1 \pm 1.2$ & 2.2 \\
\hline & $\begin{array}{c}\text { Mean } \pm \text { SD } \\
(\text { HbAlc) }\end{array}$ & $8.9 \pm 1.7$ & $7.4 \pm 1.3$ & 1.5 \\
\hline
\end{tabular}

All data is represented as mean \pm standard deviation

\subsection{Change in HbAlc in Diabetic Patients with Sulfonylurea Therapy}

Maximum level of HbAlc before therapy with sulfonyl urea therapy was 14 , after therapy the level became 12, minimum level of $\mathrm{HbAlc}$ before therapy with combination of oral antidiabetics was 8.2, after therapy the level became 5.6 and the mean level of $\mathrm{HbAlc}$ was $9.3 \pm 2.8$ and after treatment it became $7.9 \pm 1.7$ with difference equal to 1.4 (\%) (Table 3).

\subsection{Change in HbAlc in Diabetic Patients with Combination Therapy}

Maximum level of $\mathrm{HbAlc}$ before therapy with combination therapy was 14 , after therapy the level became 11.3, minimum level of $\mathrm{HbAlc}$ before therapy with sulfonylurea was 6.9 , after therapy the level became 6.1 and the mean level of HbAlc was $9.6 \pm 1.7$ and after treatment it became $7.7 \pm 1.3$ with difference equal to 1.9 (\%) (Table 4).

\subsection{Change in Fasting Blood Glucose in Diabetic Patients with Metformin Therapy}

Maximum level of fasting blood glucose before therapy with metformin therapy was 19.3, after therapy the level became 17.1, minimum level of fasting blood glucose before therapy with metformin was 7.4 , after therapy the level became 5.1 and the mean level of fasting blood glucose was $10.2 \pm 3.0$ and after treatment it became $8.4 \pm$ 2.7 with difference equal to $1.8(\mathrm{mmol} / \mathrm{l})$ (Table 5$)$.

\subsection{Change in Fasting Blood Glucose in Diabetic Patients with Sulfonylurea Therapy}

Maximum level of fasting blood glucose before therapy with metformin therapy was 18.7 , after therapy the level became 16.3, minimum level of fasting blood glucose before therapy with metformin was 7.1, after therapy

Table 3. Difference in HbAlc level caused by sulfonyl urea therapy $(\mathrm{n}=70)$

\begin{tabular}{|c|c|c|c|c|}
\hline \multicolumn{2}{|c|}{ Variable } & $\begin{array}{c}\text { Before therapy with } \\
\text { sulfonylurea } \\
(\%)\end{array}$ & $\begin{array}{c}\text { After therapy with sulfonylurea } \\
\text { (\%) }\end{array}$ & Difference (\%) \\
\hline \multirow{5}{*}{ sulfonylurea therapy } & $\begin{array}{c}\text { Maximum } \\
\text { (HbA1c) }\end{array}$ & $14 \pm 1.1$ & $12 \pm 1.4$ & 2 \\
\cline { 2 - 5 } & $\begin{array}{c}\text { Minimum } \\
(\text { HbA1c) }\end{array}$ & $8.2 \pm 1.5$ & $5.6 \pm 1.9$ & 2.6 \\
\cline { 2 - 5 } & $\begin{array}{c}\text { Mean } \pm \text { SD } \\
(\text { HbAlc) }\end{array}$ & $9.3 \pm 2.8$ & $7.9 \pm 1.7$ & 1.4 \\
\hline
\end{tabular}

All data is represented as mean \pm standard deviation 
Table 4. Difference in HbAlc level caused by combination therapy $(\mathrm{n}=77)$

\begin{tabular}{|c|c|c|c|c|}
\hline \multicolumn{2}{|c|}{ Variable } & Before therapy with (metformin, & After therapy with (metformin, & Difference (\%) \\
\hline \multirow{3}{*}{$\begin{array}{l}\text { Combination } \\
\text { therapy } \\
\text { (metformin, } \\
\text { sulfonylurea) }\end{array}$} & $\begin{array}{c}\text { Maximum } \\
(\mathrm{HbA} 1 \mathrm{c})\end{array}$ & $14 \pm 1.9$ & $11.3 \pm 1.5$ & 2.7 \\
\hline & $\begin{array}{c}\text { Minimum } \\
(\mathrm{HbA} 1 \mathrm{c})\end{array}$ & $6.9 \pm 1.8$ & $6.1 \pm 1.2$ & 0.8 \\
\hline & $\begin{array}{c}\text { Mean } \pm \text { SD } \\
(\text { HbA1c })\end{array}$ & $9.6 \pm 1.7$ & $7.7 \pm 1.3$ & 1.9 \\
\hline
\end{tabular}

All data is represented as mean \pm standard deviation

Table 5. Difference in fasting blood glucose caused by metformin therapy $(\mathrm{n}=70)$

\begin{tabular}{|c|c|c|c|c|}
\hline \multicolumn{2}{|c|}{ Variable } & $\begin{array}{c}\text { Before therapy with metformin } \\
(\mathbf{m m o l} / \mathbf{l})\end{array}$ & $\begin{array}{c}\text { After therapy with metformin } \\
\text { (mmol/l) }\end{array}$ & Difference \\
\hline \multirow{3}{*}{$\begin{array}{c}\text { Metformin } \\
\text { therapy }\end{array}$} & $\begin{array}{c}\text { Maximum (fasting } \\
\text { blood glucose) }\end{array}$ & $19.3 \pm 3.6$ & $17.1 \pm 3.4$ & 2.2 \\
\cline { 2 - 5 } & $\begin{array}{c}\text { Minimum } \\
\text { (fasting blood glucose) }\end{array}$ & $7.4 \pm 2.9$ & $5.1 \pm 3.2$ & 2.3 \\
\cline { 2 - 5 } & $\begin{array}{c}\text { Mean } \pm \text { SD } \\
\text { (fasting blood glucose) }\end{array}$ & $10.2 \pm 3.0$ & $8.4 \pm 2.7$ & 1.8 \\
\hline
\end{tabular}

All data is represented as mean \pm standard deviation

the level became 5.3 and the mean level of fasting blood glucose was $11.7 \pm 3.1$ and after treatment it was $10.1 \pm$ 2.4 With difference equal to $1.6(\mathrm{mmol} / \mathrm{l})$ (Table 6).

\subsection{Change in Fasting Blood Glucose in Diabetic Patients with Combination Therapy}

Maximum level of fasting blood glucose before therapy with metformin therapy was 23 , after therapy the level became 17.8, minimum level of fasting blood glucose before therapy with metformin was 7.8 , after therapy the level became 5.1 and the mean level of fasting blood glucose was $13.4 \pm 4.3$ and after treatment it was $10.4 \pm$ 3.7 With difference equal to $3(\mathrm{mmol} / \mathrm{l})$ (Table 7$)$.

\subsection{Change in Postprandial Blood Glucose in Diabetic Patients with Metformin Therapy}

Maximum level of postprandial blood glucose before therapy with metformin therapy was 23 , after therapy the level became 20.8, minimum level of postprandial blood glucose before therapy with metformin was 7.1, after therapy the level became 5.2 and the mean level of postprandial blood glucose was $15.6 \pm 4.8$ and after

Table 6. Difference in fasting blood glucose caused by sulfonylurea therapy ( $\mathrm{n}=70)$

\begin{tabular}{|c|c|c|c|c|}
\hline \multicolumn{2}{|c|}{ Variable } & $\begin{array}{c}\text { Before therapy with } \\
\text { sulfonylurea (mmol/l) }\end{array}$ & $\begin{array}{c}\text { After therapy with sulfonylurea } \\
\text { (mmol/l) }\end{array}$ & Difference \\
\hline \multirow{3}{*}{$\begin{array}{c}\text { Sulfonylurea } \\
\text { therapy }\end{array}$} & $\begin{array}{c}\text { Maximum (fasting blood } \\
\text { glucose) }\end{array}$ & $\begin{array}{c}\text { Minimum (fasting blood } \\
\text { glucose) }\end{array}$ & $7.1 \pm 2.3 \pm 2.4$ & $5.3 \pm 2.2$ \\
\cline { 2 - 5 } & $\begin{array}{c}\text { Mean } \pm \text { SD (fasting blood } \\
\text { glucose) }\end{array}$ & $11.7 \pm 3.1$ & $10.1 \pm 2.4$ & 1.8 \\
\hline
\end{tabular}

All data is represented as mean \pm standard deviation 
Table 7. Difference in fasting blood glucose caused by combination therapy $(n=77)$

\begin{tabular}{|c|c|c|c|c|}
\hline \multicolumn{2}{|c|}{ Variable } & Before therapy with (metformin, & After therapy with (metformin, & Difference \\
\hline \multirow{3}{*}{$\begin{array}{c}\text { Combination } \\
\text { Therapy } \\
\text { (metformin, } \\
\text { sulfonylurea) }\end{array}$} & $\begin{array}{c}\text { Maximum (fasting } \\
\text { blood glucose) }\end{array}$ & $23 \pm 4.3$ & $17.8 \pm 3.4$ & 5.2 \\
\hline & $\begin{array}{c}\text { Minimum (fasting } \\
\text { blood glucose) }\end{array}$ & $7.8 \pm 3.6$ & $5.1 \pm 2.8$ & 2.7 \\
\hline & $\begin{array}{c}\text { Mean } \pm \text { SD } \\
\text { (fasting } \quad \text { blood } \\
\text { glucose) }\end{array}$ & $13.4 \pm 4.3$ & $10.4 \pm 3.7$ & 3 \\
\hline
\end{tabular}

All data is represented as mean \pm standard deviation

treatment it was $12.4 \pm 4.2$ with difference equal to $3.2(\mathrm{mmol} / \mathrm{l})$ (Table 8$)$.

\subsection{Change in Postprandial Blood Glucose in Diabetic Patients with Sulfonylurea Therapy}

Maximum level of postprandial blood glucose before therapy with metformin therapy was 30.7 , after therapy the level became 27.7, minimum level of postprandial blood glucose before therapy with metformin was 8.3 , after therapy the level became 5.1 and the mean level of postprandial blood glucose was $13.4 \pm 4.3$ and after treatment it was $10.4 \pm 3.7$ with difference equal to 3(mmol/l) (Table 9).

\subsection{Change in Postprandial Blood Glucose in Diabetic Patients with Combination Therapy}

Maximum level of postprandial blood glucose before therapy with metformin therapy was 27.2 , after therapy the level became 23.8, minimum level of postprandial blood glucose before therapy with metformin was 7.8 , after therapy the level became 4.2 and the mean level of postprandial blood glucose was $14.8 \pm 4.3$ and after treatment it was $11.1 \pm 3.7$ with difference equal to $3.7(\mathrm{mmol} / \mathrm{l})$ (Table 10$)$.

\subsection{Comparison between the Effect of the Three Modalities of Treatment on HbA1c Level}

There was a significant difference between levels of HbAlc between metformin group and combination group (metformin and sulfonylurea) $(\mathrm{p}=0.002)$ and also there was a significant difference between sulfonylurea group and combination group (metformin and sulfonylurea) in relation to HbAlc levels ( $\mathrm{p}=$ $0.001)$. However, there was no significant difference between metformin and sulfonylurea in decreasing $\operatorname{HbA1c}(\mathrm{p}=0.09)$.

Table 8. Difference in postprandial blood glucose caused by metformin therapy $(n=70)$

\begin{tabular}{|c|c|c|c|c|}
\hline \multicolumn{2}{|c|}{ Variable } & $\begin{array}{l}\text { Before therapy with } \\
\text { metformin ( } \mathrm{mmol} / \mathrm{l})\end{array}$ & $\begin{array}{l}\text { After therapy } \\
\text { with metformin }\end{array}$ & Difference \\
\hline \multirow{3}{*}{ Metformin therapy } & $\begin{array}{l}\text { Maximum(post } \\
\text { prandial blood glucose) }\end{array}$ & $23 \pm 4.3$ & $20.8 \pm 3.5$ & 2.2 \\
\hline & $\begin{array}{c}\text { Minimum } \\
\text { (post prandial blood glucose) }\end{array}$ & $7.1 \pm 3.3$ & $5.2 \pm 2.6$ & 1.9 \\
\hline & $\begin{array}{c}\text { Mean } \pm \text { SD } \\
\text { (post prandial blood glucose) }\end{array}$ & $15.6 \pm 4.8$ & $12.4 \pm 4.2$ & 3.2 \\
\hline
\end{tabular}

All data is represented as mean \pm standard deviation 
Table 9. Difference in postprandial blood glucose caused by sulfonylurea therapy $(n=70)$

\begin{tabular}{|c|c|c|c|c|}
\hline \multicolumn{2}{|c|}{ Variable } & $\begin{array}{c}\text { Before therapy with } \\
\text { metformin (mmol/l) }\end{array}$ & $\begin{array}{c}\text { After therapy with } \\
\text { metformin } \\
\text { (mmol/l) }\end{array}$ & Difference \\
\hline \multirow{3}{*}{ Metformin therapy } & $\begin{array}{c}\text { Maximum (post } \\
\text { prandial bloodglucose) }\end{array}$ & $30.7 \pm 4.3$ & $5.1 \pm 2.6$ & 3.2 \\
\cline { 2 - 5 } & $\begin{array}{c}\text { Minimum (post prandial } \\
\text { blood glucose) }\end{array}$ & $8.3 \pm 3.3$ & $10.4 \pm 3.7$ & 3.2 \\
\cline { 2 - 5 } & $\begin{array}{c}\text { Mean } \pm \text { SD (post prandial } \\
\text { blood glucose) }\end{array}$ & $13.4 \pm 4.3$ & 3.7 \\
\hline
\end{tabular}

Table 10. Difference in post prandial blood glucose caused by combination therapy $(n=77)$

\begin{tabular}{|c|c|c|c|c|}
\hline \multicolumn{2}{|c|}{ Variable } & \multirow{2}{*}{$\begin{array}{c}\begin{array}{c}\text { Before therapy with } \\
\text { (metformin, sulfonylurea) } \\
(\mathbf{m m o l} / \mathbf{l})\end{array} \\
27.2 \pm 4.0\end{array}$} & \multirow{2}{*}{$\begin{array}{l}\text { After therapy with (metformin, } \\
\text { sulfonylurea) (mmol/l) } \\
\qquad 23.8 \pm 4.2\end{array}$} & \multirow{2}{*}{$\begin{array}{c}\text { Difference } \\
3.4\end{array}$} \\
\hline \multirow{3}{*}{$\begin{array}{l}\text { Combination } \\
\text { therapy } \\
\text { (metformin, } \\
\text { sulfonylurea) }\end{array}$} & $\begin{array}{l}\text { Maximum (post } \\
\text { prandial blood } \\
\text { glucose) }\end{array}$ & & & \\
\hline & $\begin{array}{c}\text { Minimum } \\
\text { (post prandial blood } \\
\text { glucose) }\end{array}$ & $7.8 \pm 3.8$ & $4.2 \pm 3.2$ & 3.6 \\
\hline & $\begin{array}{c}\text { Mean } \pm \text { SD } \\
\text { (post prandial blood } \\
\text { glucose) }\end{array}$ & $14.8 \pm 4.3$ & $11.1 \pm 3.7$ & 3.7 \\
\hline
\end{tabular}

\section{Discussion}

The aim of the present study was to compare efficacy of metformin and sulfonylurea in mono therapy or combination for type 2 diabetes. The study included (63\%) males and (37\%) female diabetic patients, mean age of study subjects was 50.3 years.

Treatment with metformin and sulfonylurea primarily targets insulin resistance and insulin deficiency of type 2 diabetes which may account for greater effects on glycemic control. The results indicated that monotherapy with metformin or sulfonylurea caused comparable decrease in the level of HbAlc and fasting blood glucose in type 2 diabetic patients but metformin cause higher decrease in the level of $\mathrm{HbAlc}$, fasting and post prandial blood glucose (HbAlc:1.5\% for metformin, $1.4 \%$ for sulfonylurea, fasting blood glucose: $1.8(\mathrm{mmol} / \mathrm{l})$ for metformin, 1.6( $\mathrm{mmol} / \mathrm{l})$ for sulfonylurea and post prandial blood glucose:3.2( $\mathrm{mmol} / \mathrm{l})$ for metformin, $3(\mathrm{mmol} / \mathrm{l})$ for sulfonylurea and $3.7(\mathrm{mmol} / \mathrm{l})$ for combination therapy) and also, the combination therapy cause decrease in $\mathrm{HbA1c}$ and fasting blood glucose with much higher level which is similar to what is reported in previous study which indicated that most oral hypoglycemic work with the same efficacy in lowering blood glucose when used as monotherapy as measured by hemoglobin Alc (HbAlc). They lower HbAlc about 1 percentage point on average (i.e., HbAlc can go from 8 percent to 7 percent after a medication is started). An exception was metformin, which reduced $\mathrm{HbAlc}$ levels more than other antidiabetics used as monotherapy. Combination therapy (including the combination of metformin and sulfonylurea) decreased HbAlc levels more than monotherapy did, by about 1 absolute percentagepoint ${ }^{29}$.

A previous systemic review analyzing the results of 15 controlled studies on treatment with metformin versus control reported a weighted mean absolute difference in HbAlc levels of $1.14 \%{ }^{30}$ which is similar to the present study results. Also, many reports refer to a reduction of HbAlc by $1-2 \%{ }^{31}$.

Sulphonylureas are effective antihyperglycaemic agents that reduce $\mathrm{HbAlc}$ by greater than $1 \%$ in monotherapy regimens ${ }^{31}$. Analysis of 11 controlled studies of monotherapy with sulfnylurea against control 
found that the weighted mean decrease in $\mathrm{HbAlc}$ was $1.52^{30}$ which is higher than the present study results.

Some companies produce formulae that contain MET in addition to another medication. These drugs have been oral antihyperglycaemic agents suggested to encourage patient compliance as a result of reduced pill burden. The bioavailability, tolerability and efficacy of these combinations were similar to the individual components in dual therapy ${ }^{32}$. Patients who switched from dual therapy to fixed combination had a $12.4 \%$ increase in adherence to medication ${ }^{33}$. One of their major limitations involves the lack of flexibility of the dose. In some combinations, metformin is available in an extended release formula. In other combination, it is available as an immediate release formula, which may not be tolerated by some patients ${ }^{34}$. The results supported by another evidence indicated that combinations of metformin and a sulfonylurea reduces HbAlc more than using metformin or a sulfonylurea alone.

Sulfonylureas cause hypoglycemia than metformin. It occurs in about 14 percent of people taking a sulfonylurea and 12 percent of people taking repaglinide but the current results didn't show any evidence of hypoglycemia with sulfonylurea ${ }^{29}$.

The risk of hypoglycemia increases with combination therapy. People taking a combination of oral hypoglycemics have about an 11-percent higher risk than people on monotherapy which is obvious in this present study results from the difference in $\mathrm{HbAlc}$ level between before and after therapy ${ }^{29}$.

\subsection{Limitations of the Study}

First, not all types of sulfonylurea included in the study because only the types present at the hospital where the study conducted were included.

Second, the results can't be generalized as we used the data from a single district general hospital.

Third, the small sample size according to inclusion criteria of the study as the proportion of patients with laboratory test results, such as $\mathrm{HbAlc}$, for both baseline and after oral antidiabetic treatment for at least three months was low as this observational study was conducted in a real-world setting.

Fourthly, the study didn't put into consideration other co morbid conditions or other medication taken by the patients of the study sample.

\section{Conclusion and Recommendation}

In conclusion, metformin or sulfonylurea as a single therapy are similar in efficacy in reducing glycosylated hemoglobin level, fasting and post-prandial plasma glucose levels to equal degree. However, combination of both therapies resulted in significant greater control of blood glucose level.

Further research with experimental studies as well as large scale RCTs with good study design, long-term follow up are needed on this topic.

\section{References}

1. Mendis S Global status report on noncommunicable diseases; 2014.

2. Al-Hazzaa HM. Prevalence of physical inactivity in Saudi Arabia: A brief review. Eastern Mediterranean Health Journal. 2004; 10:663-70.

3. Elhadd TA, Al-Amoudi AA, Alzahrani AS. Epidemiology, clinical and complications profile of diabetes in Saudi Arabia: A review. Annals of Saudi Medicine. 2007; 27:241-50. https://doi.org/10.5144/0256-4947.2007.241. PMid:17684435. PMCid:PMC6074292

4. Al-Nozha MM, Al-Maatouq MA, Al-Mazrou YY, Al-Harthi SS, Arafah MR, Khalil MZ, et al. Diabetes mellitus in Saudi Arabia. Saudi Medical Journal. 2004; 25:1603-10.

5. Swinburn B. Sustaining dietary changes for preventing obesity and diabetes: Lessons learned from the successes of other epidemic control programs. Asia Pacific Clinical Nutrition Society. 2002; 11(Suppl 3):S598-606. https://doi. org/10.1046/j.1440-6047.11.supp3.3.x. PMid:12492653

6. Hussain A, Claussen B, Ramachandran A, Williams R. Prevention of type 2 diabetes: A review. Diabetes Research and Clinical Practice. 2007; 76:317-26. https://doi. org/10.1016/j.diabres.2006.09.020. PMid:17069920

7. DeFronzo RA. Pharmacologic therapy for type 2 diabetes mellitus. Annals of Internal Medicine. 1999; 131:281-303. https://doi.org/10.7326/0003-4819-131-4-199908170-00008. PMid: 10454950

8. Wolfs M, Hofer MH, Wijmenga C, van Haeften TW. Type 2 diabetes mellitus: New genetic insights will lead to new therapeutics. Current Genomics. 2009; 10:110-18. https:// doi.org/10.2174/138920209787847023. PMid:19794883. PMCid:PMC2699827

9. Power A, Fauci A, Kasper D, et al. Diabetes mellitus. Harrison's principle of medicine.16 ${ }^{\text {th }}$ edit. 2007; 14(323):2152-8. 
10. Feinglos MN, Bethel MA. Treatment of type 2 diabetes mellitus. Medical Clinics of North America. 1998; 82:75790. https://doi.org/10.1016/S0025-7125(05)70023-7

11. American Diabetes Association. The pharmacological treatment of hyperglycemia in NIDDM. Diabetes Care. 1995; 18:1510-8. https://doi.org/10.2337/diacare.18.11.1510. PMid:8722084

12. Alwakeel JS, Al-Suwaida A, Isnani AC, Al-Harbi A, Alam A. Concomitant macro and micro-vascular complications in Diabetic nephropathy. Saudi Journal of Kidney Diseases and Transplantation. 2009; 20:402-9.

13. Tabish, SA. Is diabetes becoming the biggest epidemic of the twenty-first century? International Journal of Health Sciences. 2007; 1(2):V-VIII.

14. The Ministry of Health. Statistics Report; 2015.

15. Kearns K, Dee A, Fitzgerald AP, Doherty E, Perry IJ. Chronic disease burden associated with overweight and obesity in Ireland: The effects of a small BMI reduction at population level. BMC Public Health. 2014; 14. https://doi.org/10.1186/14712458-14-143. PMid:24512151. PMCid:PMC3929131

16. Al-Rubeaan K. National surveillance for type 1 , type 2 diabetes and prediabetes among children and adolescents: A population-based study (SAUDI-DM). Journal of Epidemiology and Community Health. 2015; 69(11):1045-51. https://doi.org/10.1136/jech-2015-205710. PMid:26085648. PMCid:PMC4680138

17. Al-Nozha, Mansour M, et al. Diabetes mellitus in Saudi Arabia. Saudi Medical Journal. 2004; 25,11:1603-10.

18. Al-Rubeaan, K, Al-Manaa HA, Khoja TA, Ahmad NA, AlSharqawi AH, Siddiqui K, et al. Epidemiology of abnormal glucose metabolism in a country facing its epidemic: SAUDI-DM study. Journal of Diabetes. 2015; 7(5):622-32. https://doi.org/10.1111/1753-0407.12224. PMid:25266306

19. Al-Daghri NM, Al-Attas OS, Alokail MS, Alkharfy KM, Yousef M, Sabico SL, et al. Diabetes mellitus type 2 and other chronic non-communicable diseases in the central region, Saudi Arabia (Riyadh cohort 2): A decade of an epidemic. BMC Medicine. 2011 Jun; 9(76). https://doi.org/10.1186/17417015-9-76. PMid:21689399 PMCid:PMC3141541

20. Alqurashi, Khalid A et al. Prevalence of diabetes mellitus in a Saudi community. Annals of Saudi Medicine. 2011; 31(1):1923. https://doi.org/10.4103/0256-4947.75773. PMid:21245594. PMCid:PMC3101719

21. Al-Baghli, NA, Al-Ghamdi AJ, Al-Turki KA, Al Elq AH, El-Zubaier AG, Bahnassy A. Prevalence of diabetes mellitus and impaired fasting glucose levels in the Eastern Province of Saudi Arabia: Results of a screening campaign. Singapore Medical Journal. 2010; 51(12):923-30.

22. Tosi F, Muggeo M, Brun E, Spiazzi G, Perobelli L, Zanolin E, et al. Combination treatment with metformin andvglibenclamide versus single-drug therapies in type 2 diabetes mellitus: A randomized, double-blind, comparative study. Metabolism. 2003; 52(7):862-7. https://doi.org/10.1016/S0026-0495(03)00101-X

23. Inzucchi SE, Bergenstal RM, Buse JB, Diamant $M$, Ferrannini E, Nauck M, et al. Management of hyperglycaemia in type 2 diabetes: A patient-centered approach. Position statement of the American Diabetes Association (ADA) and the European Association for the Study of Diabetes (EASD) Diabetologia. 2012; 55:1577-96. https://doi.org/10.1007/ s00125-012-2534-0. PMid:22526604

24. Bennett WL, Maruthur NM, Singh S, Segal JB, Wilson LM, Chatterjee $\mathrm{R}$, et al. Comparative effectiveness and safety of medications for type 2 diabetes: An update including new drugs and 2-drug combinations. Annals of Internal Medicine. 2011; 154:602-13. https://doi.org/10.7326/00034819-154-9-201105030-00336. PMid:21403054. PMCid:PMC3733115

25. American Diabetes Association. Standards of medical care in diabetes 2009. Diabetes Care. 2009; 32(1):15. https://doi. org/10.2337/dc09-S013. PMid:19118286. PMCid:PMC2613589

26. Stephenne $X$, Foretz $M$, Taleux $N$, et al. Metformin activates AMP activated protein kinase in primary human hepatocytes by decreasing cellular energy status. Diabetologia. 2011; 54:3101-10. https://doi.org/10.1007/ s00125-011-2311-5. PMid:21947382. PMCid:PMC3210354

27. Triplitt C, Reasner C. Chapter 83: diabetes mellitus. In DiPiro JT, Talbert RL, Yee GC, Matzke GR, Wells BG, Posey LM. Pharmacotherapy: A pathophysiologic approach (8th ed.). New York, NY: McGraw-Hill. 2011; 27:1274.

28. Draeger KE, Wernicke-Panten K, Lomp HJ, Schuler E, Rosskamp R. Long-term treatment of Type 2 diabetic patients with the new oral antidiabetic agent glimepiride (Amaryl): A double-blind comparison with glibenclamide. Hormone and Metabolic Research. 1996 Sep; 28:419-25. https://doi.org/10.1055/s-2007-979830. PMid:8911976

29. Eisenberg Center at Oregon Health \& Science University. Comparing oral medications for adults with Type 2 diabetes: Clinician's Guide [Internet]. 2007 Dec 5. In: Comparative Effectiveness Review Summary Guides for Clinicians. Rockville (MD): Agency for Healthcare Research and Quality (US). 2007. Available from: https:// www.ncbi.nlm.nih.gov/books/NBK43418/

30. Bolen S, Feldman L, Vassy J, Wilson L, Yeh HC, Marinopoulos S, et al. Systematic review: Comparative effectiveness and safety of oral medications for type 2 diabetes mellitus. Annals of Internal Medicine. 2007; 147. https://doi.org/10.7326/0003-4819-147-6-20070918000178. PMid:17638715

31. Inzucchi SE. Oral antihyperglycemic therapy for type 2 diabetes scientific review. Journal of the American Medical Association. 2002; 287. https://doi.org/10.1001/ jama.287.3.360. PMid:11790216 
32. Blonde L, San Juan ZT. Fixed-dose combinations for treatment of type 2 diabetes mellitus. Advances in Therapy. 2012; 29. https://doi.org/10.1007/s12325-011-0094-1. PMid:22271157

33. Cheong C, Barner JC, Lawson KA, Johnsrud MT. Patient adherence and reimbursement amount for antidiabetic fixed dose combination products compared with dual therapy among Texas Medicaid recipients. Clinical Therapeutics. 2008; 30. https://doi.org/10.1016/j.clinthera.2008.10.003. PMid:19014846

34. Blonde L, San Juan ZT, Bolton P. Fixed-dose combination therapy in type2 diabetes mellitus. Endocrine Practice. 2014; 20. https://doi.org/10.4158/EP14259.RA. PMid:25370323 